\title{
The Impact of Adolescent Risk Behavior on Partner Relationships
}

\author{
Terence P. Thornberry ${ }^{\mathrm{a}}$ \\ Marvin D. Krohn ${ }^{\mathrm{b}}$ \\ Megan Bears Augustyn ${ }^{c}$ \\ Molly Buchanan ${ }^{\mathrm{b}}$ \\ Sarah Greenman $^{\mathrm{d}}$
}

${ }^{a}$ Department of Criminology and Criminal Justice, 2220 LeFrak Hall, University of Maryland, College Park, MD 20742, thornbet@umd.edu; telephone: 3039032747.

${ }^{\mathrm{b}}$ Department of Sociology and Criminology \& Law, University of Florida, P.O. Box 117330 Gainesville, FL 32611, mkrohn@ufl.edu; telephone: 3522947178.

${ }^{\mathrm{c}}$ Department of Criminal Justice, $501 \mathrm{~W}$. Cesar Chavez Blvd., The University of Texas at San Antonio, San Antonio, TX 78207, megan.augustyn@utsa.edu; telephone: 2104582976.

d Department of Criminal Justice and Forensic Science, 1536 Hewitt Ave, Hamline University, St. Paul, MN 55104, sgreenman01@hamline.edu; 6515232075.

\section{Acknowledgments}

Support for the Rochester Youth Development Study has been provided by the Centers for Disease Control and Prevention (R01CE001572), the Office of Juvenile Justice and Delinquency Prevention (2006-JW-BX-0074, 86-JN-CX-0007, 96-MU-FX-0014, 2004-MU-FX-0062), the National Institute on Drug Abuse (R01DA020195, R01DA005512), the National Science Foundation (SBR-9123299), and the National Institute of Mental Health (R01MH56486, R01MH63386). Work on this project was also aided by grants to the Center for Social and Demographic Analysis at the University at Albany from NICHD (P30HD32041) and NSF (SBR9512290). Points of view or opinions in this document are those of the authors and do not necessarily represent the official position or policies of the funding agencies. 


\begin{abstract}
Prior literature suggests that involvement in adolescent risk behaviors will have shortand long-term consequences that disrupt the orderly flow of later development, including impacts on patterns of partner relationships. In this study, we explore how adolescent involvement in delinquency, drug use, and sexual behavior at an early age affect the likelihood and timing of both marriage and cohabitation using a sample from the Rochester Youth Development Study. We also examine the direct effects of dropping out of high school, teenage parenthood, and financial stress during emerging adulthood as well as their potential role as mediators of the relationships between adolescent risk behaviors and partnering for both males and females. Overall, there is not very strong support for a direct relationship between adolescent delinquency, drug use, or early sexual behavior and patterns of partner formation. In contrast, the more proximal relationships, indicated by precocious transitions to adulthood and financial instability are more consistently related to partner formation. These findings support models of cumulative disadvantage: early adolescent problem behaviors are weakly related to partner formation, but appear to set in motion cascading consequences that influence the transition to adulthood and, in turn, these more proximal variables are more consistently related to partner formation.
\end{abstract}

Keywords: Adolescent Antisocial Behavior; Partner Relationships; Life-Course Criminology; Precocious Transitions 
The life course approach places substantial emphasis on transitions, or short-term changes in the life course. Transitions represent movement along age-graded patterns of development, or trajectories, such as family, school, work, and romantic relationships (Elder, 1994). Marriage and, in today's society, cohabitation, are important transitions in one's life course and often influence how successful a person will be in adulthood. Understanding the origins of these transitions, therefore, is an important task for life course studies.

Trajectories do not exist in a vacuum, however. Movement along one trajectory is expected to influence movement along other trajectories. More specifically, involvement in adolescent risk behaviors which compromise adolescent development (Busseri, Willoughby, \& Chalmers, 2007; Jessor, 1998) can be conceptualized as their own life course trajectories (Thornberry \& Krohn, 2001). As such, we would expect early involvement in these risk behaviors including delinquency, drug use, and risky sexual behavior to influence transitions into other trajectories such as establishing a relationship with a significant other. However, relatively little theoretical and empirical attention is given to the impact of engagement in adolescent risk behavior on patterns of partner formation (King \& South, 2011). The current study addresses this issue by focusing on how adolescent risk behavior impacts the likelihood of forming an intimate relationship with a significant other and whether that relationship is formalized through marriage or is characterized by the more informal relationship of cohabitation.

\section{Theoretical Framework}

Most criminological studies that incorporate some measure of partnering or the quality of partner relationships typically examine the effect of entering a romantic relationship and/or the quality of that relationship on subsequent crime (Farrington \& West, 1995; Giordano, Cernkovich, \& Rudolph, 2002; Laub, Nagin, \& Sampson, 1998; Sampson \& Laub, 1993; Warr, 
1998). Siennick and Osgood (2008) document that the effect of marriage on desistance has received more attention than any other social bond or related life-course factor. However, exploration of the influence of deviant and criminal behaviors on partner formation is sparse (King \& South, 2011).

We use Thornberry's (1987) interactional theory as a framework to discuss the potential effects of adolescent risk behaviors on partner formation. Interactional theory was one of the first to emphasize the importance of examining the effect of crime and related problem behaviors on later life course development. Thornberry and Krohn (2001) extended the original focus of that theory from adolescence to include the adult years, as well as the transition from adolescence to adulthood.

Thornberry and Krohn (2001) suggest that engaging in problem or risk behavior during adolescence can set in motion a 'cascading' set of both co-morbid and future consequences that adversely affects the chances for successful life course development. In the life course literature, this is typically referred to as cumulative continuity or cumulative disadvantage (Dannefer, 2003). The process that Thornberry and Krohn (2001) describe relies heavily on their hypothesis that engaging in risk behavior during adolescence serves as a precursor or gateway to other maladaptive behaviors. These risk behaviors, which include involvement in delinquency, drug use, and risky sexual behavior including early sexual debut, often co-occur and are part of a larger manifestation for a proclivity to engage in potentially harmful or dangerous behavior that have both immediate (adolescent) and long-term (adult) consequences on development (Busseri, Willoughby, \& Chalmers, 2007; Jessor, 1998; Metzler et al., 1994). This is in line with Thornberry and Krohn (2001) who argue that engaging in each of these risk behaviors increases the probability that an adolescent will experience disorderly and off-time transitions into 
adulthood. In other words, transitions to adulthood including stopping one's education, becoming a parent, and financial independence occur prior to the time when they would be optimal for successful entry into adult life (Rindfuss, Swicegood, \& Rosenfeld, 1987; Wickrama, Wickrama, \& Baltimore. 2010). Substantiating this argument, research demonstrates that dropping out of high school or having a child during one's teenage years are precocious transitions that are empirically linked to prior involvement in adolescent risk behavior (Fagan \& Pabon, 1990; Krohn, Lizotte, \& Perez, 1997; Krohn, Thornberry, Collins-Hall, \& Lizotte, 1995; Newcomb \& Bentler, 1988).

Such precocious transitions, in turn, place these youth at a distinct disadvantage in acquiring the human and social capital necessary for successfully adopting adult roles. For instance, failing to graduate from high school and/or becoming a teenage parent contributes to a decreased likelihood of obtaining the credentials necessary for job market success and financial independence (Coley \& Chase-Lansdale, 1998; Lanctot, Cernkovich, \& Giordano, 2007; Thornberry, Smith, \& Howard, 1997). Because of the failure to complete high school or the acquisition of additional financial burdens associated with teenage parenthood these youth are in a disadvantageous positions to obtain employment, especially employment that is stable and well-paying (Arum \& Beattie, 1999; Blomberg, Bales, Mann, Piquero, \& Berk, 2011; Clausen, 1986; Elman \& O’Rand, 2004; Tanner, Davies, \& O’Grady, 1999). Along the same line, individuals with histories of involvement in risk behavior are more likely to experience intermittent periods of unemployment, have lower incomes, and receive some form of welfare (Bernburg \& Krohn, 2003).

Of course, youth who engage in problem or risk behaviors during adolescence are also more likely to persist in maladaptive behaviors into young adulthood than youth who toe the line 
(Thornberry \& Krohn, 2001; see also Armour \& Haynie, 2006). For such youth, it is likely that their past and future problem behavior will both directly and indirectly affect their opportunities for success over the life course.

Thus, interactional theory suggests that the cumulative disadvantage generated by adolescents' participation in problem or risk behaviors increases the likelihood that they will have less educational attainment, experience teenage pregnancy and parenthood, have poorer job prospects and ensuing unemployment issues, and earn lower incomes increasing the likelihood of being on welfare or receiving some other form of financial assistance. In addition, they will be more likely to continue to engage in problem behaviors as young adults. As we will note in the next section, these characteristics do not bode well for an individuals' value on the marriage market. In other words, the cascading life course consequences of earlier adolescent risk behavior are likely to have direct effects on the formation of subsequent partner relationships and facilitate precocious transitions into adulthood that will serve as important mediators of the impact of problem or risk behaviors on patterns of union formation.

\section{Deciding to Partner}

Traditional theory on the decision to marry has focused on how potential partners can enhance one's life chances (Becker, 1981; Oppenheimer, Kalmijn \& Lim, 1997). Becker (1981) views the process of choosing a romantic partner as the evaluation of potential mates as a “trading partner". That is, potential partners will assess whether a marriage relationship will be beneficial in terms of the mutual exchange of qualities, skills, and material goods, including income. Although many economic and cultural changes have occurred since Becker (1981) posited his theory, the main focus of partner assessment is the potential earning capacity and ability to assist in successfully attaining financial security. A crucial attribute in the assessment 
of a prospective partners' earning potential is their level of educational attainment (Oppenheimer et al., 1997). However, partner consideration of resourcess beyond educational and financial potential are also documented (Kalmijn, 1998) .

Edin, Kefalas, and Reed (2004) found that, among disadvantaged populations, not only is a financial portfolio that ensures economic "arrival" often a prerequisite for marriage but additional characteristics are commonly considered as well. These are categorized as affordability, respectability, control, trust, and domestic violence. Affordability refers to the projected earning capacity of potential partners. Respectability includes consideration of whether potential partners are unemployed, underemployed or involved in criminal enterprises and how this may affect their status in society. Control refers to women's desire to remain autonomous in their childrearing practices and not become subservient to their partner once relationships are formalized through union formation or marriage. Trust is an important concern, especially with partners who have had several unsuccessful relationships in the past. Finally, concerns about domestic violence and increased chances of criminal victimization that might spillover from prior involvement in serious crime are factors considered when deciding to enter into long-term cohabiting or marriage relationships (Edin, 2000; King \& South, 2011).

While it is recognized that not everyone makes rational decisions when selecting significant others, it seems clear that factors, such as those outlined above, influence patterns of relationship formation. Individuals' involvement in criminal behavior, drug use, and risky sexual activities are expected to affect, both directly and indirectly, how potential partners evaluate the resources that a partner can bring into a relationship as well as how much potential partners can respect and trust the significant other. Additionally, concerns about how a potential partner's involvement in problem behaviors place an individual at risk for abuse, exposure to 
criminal networks, or sexually transmitted diseases are also likely to arise. In the next section, we examine the research on the effects of these behaviors and their potential consequences (involvement with the criminal justice system) on marriage and cohabitation.

\section{Problem Behavior and Marriageability}

Much of the research on the influence of adolescent risk or problem behaviors on marriageability and the quality of partner relationships focuses on the effects of involvement in the juvenile or criminal justice system, especially incarceration. By and large, studies support the hypothesis that involvement in the justice system decreases the probability of marrying and, if marriage occurs, involvement in the justice system increases the probability of such unions being discordant and high in conflict (Huebner, 2007; Fu \& Goldman, 2000; London \& Parker, 2009; Lopoo \& Western, 2005; Sampson \& Laub, 1993; Western, Lopoo \& McLanahan, 2004). While studies regarding the effect of incarceration on marriageability and relationship quality are informative, we are interested in the impact of adolescent risk behavior - specifically, involvement in criminal behavior, drug use, and risky sexual behavior - on subsequent partner relationships and marriage, regardless of whether these behaviors result in incarceration. The impact of involvement in the criminal justice system on partner relationships may involve effects other than those attributable directly to problem behavior, such as labeling and incapacitation (Lopoo \& Western, 2005).

King and South (2011) provide a clear statement of why criminal behavior would be expected to affect marriageability as well as a systematic investigation of their hypotheses. King and South (2011) suggest three reasons why people who have a history of criminal involvement are less desirable partners, which coincide with assertions found in Edin et al. (2004). They include: 1) perceived risks of victimization, 2) the notion that criminal behavior and marriage are 
conflicting roles (e.g., criminal behavior may be indicative of a lack of maturity and inability to self-sacrifice), and 3) offenders' poor financial prognoses. Using the first 7 waves of the National Youth Survey data, King and South (2011) find that for men, but not for women, more involvement in criminal offending is significantly related to the timing of first marriage -- that is, male offenders get married at older ages, if at all, compared to male non-offenders. However, when other predictors of marital entry, particularly a measure of desire to marry, are included, the relationship between offending and the timing of marriage is no longer significant. The authors suggest that criminal behavior, regardless of type, has no direct causal effect on the timing of first marriage.

Doherty, Green and Ensminger (2011) examined the impact of serious delinquency on the timing of first marriage and the overall likelihood of getting married. Although involvement in serious delinquent behavior was not related to the timing of first marriage, seriously delinquent males were less likely to be married than those not involved in serious delinquent behavior. Doherty et al. (2011) also looked at the impact of drug use on marital outcomes. Marijuana use significantly affected the probability of being married for both male and female users, findings consistent with other research on the impact of drug use on marriage (Collins et al., 2007; DeKlyen et al., 2006; Fu \& Goldman, 1996; Kaestner, 1997; Newcomb \& Bentler, 1985; Yamaguchi \& Kandel, 1985).

Although sex is a behavior around which partner formation is centered (Smith, 2006), involvement in risky sexual behaviors during adolescence, which includes early sexual debut (commonly defined as experiencing first sexual intercourse at or before the age of 14), having multiple partners, and infrequent condom and/or birth control usage, are also linked to problematic outcomes including subsequent criminal behavior (Armour \& Haynie, 2006), non- 
marital childbearing during adolescence (Bennett, Bloom, \& Miller, 1995; Smith, 1998), and other non-traditional family formation processes (i.e., cohabitation; Kennedy \& Bumpass, 2008; Lichter, 2012; Sassler, Miller, \& Favinger, 2009; Smith, 2006). In particular, early sexual debut may be particularly problematic for subsequent union formations. Even though premarital sex is increasingly common, youths who embark on forming intimate relationships and experience earlier sexual initiation have a longer sexual life outside of marriage (Smith, 2006). This often leads to increased numbers of sexual partners compared to those youths who delay dating or sexual initiation (Thornton, 1990; Whyte, 1990) and make them less attractive to potential spouses. Those who engage in sexual intercourse at an early age also display more precocious, impulsive or permissive attitudes in favor of cohabiting (Manning, Longmore, \& Giordano, 2007; Willoughby \& Dworkin, 2009) and are more likely to live with a romantic partner, especially at an early age (Smock, 2000; Whyte, 1990). Unfortunately, these unions tend to be short lived and often fail to result in marriage (Cherlin, 2010; Smith, 2006; Thomson \& Colella, 1992). Ironically, early sexual intercourse with an intimate partner and attempts at union formation may actually impede long-term, permanent union formation by undermining the marriage marketability of an individual (Smock, Manning, \& Porter, 2005). It is possible that both a history of numerous sexual partners and unsuccessful cohabitation(s) may challenge the perceived respectability and trust given to an individual by a prospective marriage partner.

While precocious transitions to adulthood may decrease the attractiveness of an individual on the marriage market, traditionally, one of these transitions - teenage parenthood promoted marriage, especially at an early age. Historically, teenage pregnancy and parenthood increased the likelihood of marriage between two romantic partners as individuals attempt to form a more stable, permanent relationship that is traditionally associated with parenthood and 
family formation (Bachrach, 1987; Sampson and Laub, 2003). However, these early marriages often occurred between young, unprepared teens who were ill-equipped to be parents and unprepared for the obligations and expectations associated with marriage (Moore \& Waite, 1981). However, this relationship between teenage parenthood and early marriage weakened in recent decades as the connection between procreation and marriage lessened. In fact, $33 \%$ of births were to unwed mothers in 1994 (Smith, 2006) and exceeded 40\% each year between 2008 and 2011 (Martin et al., 2013 as cited in Lichter, Sassler, \& Turner, 2014) raising the question as to whether or not the precocious transition of teenage parenthood is still related to early marriage formation.

Given the literature on adolescent risk behavior, precocious transitions, and marriage, it appears that involvement in delinquency, drug use, and early sexual activity decrease the likelihood of marriage. In addition, evidence suggests that precocious transitions such as dropping out of high school and financial instability resulting from adolescent risk behavior may further decrease the attractiveness of an individual on the marriage market and reduce the likelihood of marriage. The one exception, though, may be teenage parenthood which has been shown to increase the likelihood of early marriage in the past; however, given that marriage is not the only path to family formation (PEW, 2010) and cohabitation and single parenthood are now important contexts for childrearing in the United States (Sassler, Miller, \& Favinger, 2009), it may be unrelated to marriage or reduce the likelihood of subsequent marriage.

\section{Problem Behaviors and Cohabitation}

In recent decades, cohabitation shifted from uncommon to commonplace and this may help account for why people who engage in problem behaviors do not get married (Smock, 2000; Sassler, Miller, \& Favinger, 2009; Smock et al., 2005). Cherlin (2004) and other scholars (see 
Giddens, 1992, 1991) argue that with modern society's increased acceptance of cohabitation, divorce, and nonmarital childrearing, marriage is no longer viewed as a necessity but rather as a "capstone experience" marking one's progression into adulthood. Of particular importance to this study is how involvement in problem behaviors and their consequences impact the decision to cohabit as well as the effects of adolescent risk behaviors and precocious transitions on the timing of cohabitation.

Research shows that delinquency is positively associated with a younger age at first cohabitation and an increased overall likelihood of cohabitating for both males and females (Lonardo, Manning, Giordano, \& Longmore, 2010; Manning et al., 2007). This suggests that the less formal, less permanent nature of cohabitation may appeal to delinquents, as those with antisocial tendencies are less likely to make strong commitments and are more likely to have negative skills when it comes to nurturing a relationship with a significant other (Brown, Sanchez, Nock, \& Wright, 2006; King \& South, 2011; Stanley, Whitton, \& Markman, 2004). Drug and alcohol use are also related to an increased likelihood of cohabitation (Fu \& Goldman, 1996; Kasetner, 1997; Yamaguchi \& Kandel, 1985), which may also suggest that those who use drugs are attracted to unions that are typically short-term arrangements (i.e., median duration of 1.3 years; Smith, 2006) and require less financial commitment.

As mentioned earlier, there is also a positive relationship between risky sexual behavior, including age of sexual onset and attitudes towards cohabitation (Cunningham \& Thornton, 2004; Manning et al., 2007; Raley, Crissey \& Muller, 2007). Not surprisingly, premarital pregnancy and parenthood, which are linked with early sexual debut and involvement in delinquency, are positively associated with the decision to cohabit (Lichter \& Graefe, 2002; Lonardo et al., 2010). In fact, the decision to cohabit at an early age as a result of a pregnancy or 
parenthood may be seen as an acceptable alternative to marriage and the traditional idea of a family. Marriage is no longer viewed as necessary to legitimatize a pregnancy. "Shotgun" cohabitations are now more common and provide legitimacy to an unplanned or out of wedlock pregnancy (Lichter, Sassler, \& Turner, 2014; Rackin \& Gibson-Davis, 2012; Reed, 2006). Finally, cohabitation may be viewed as an attractive option for romantic partners experiencing financial instability because it is one potential way to accrue additional resources to make ends meet or secure financial security without the permanent commitment associated with marriage. Unfortunately, though, economic hardships among cohabiting couples increase relationship instability and undermine the quality of the romantic relationship among cohabiting couples (Hardie \& Lucas, 2010).

In sum, a pattern emerges in terms of the influence of involvement in delinquency, drug use, and early sexual activity on the likelihood of cohabitation with individuals involved in adolescent risk behavior showing an increased propensity to cohabit. Furthermore, evidence also suggests that adolescent risk behavior affects successful transitions to adult status by decreasing the likelihood of graduating from high school, increasing the likelihood of teen pregnancy and parenthood, and decreasing the likelihood of obtaining stable employment or financial stability. In turn, these precocious transitions may promote cohabitation at an earlier age as emerging adults may rush to form partner relationships that may be viewed as potentially beneficial to childrearing or financial stability.

\section{Gender, Adolescent Risk Behavior and Partner Formation}

Gender is not only important when assessing involvement in adolescent risk or problem behaviors, but it is also likely to be an important factor in the relationship between involvement in crime and subsequent partner formation processes (Leverentz, 2006; South, 2001; 
Oppenheimer, 1988). Therefore, it is important to recognize prior research on gender differences in risk behavior/offending and partner formation and how gender may impact the relationship between these trajectories. Prior research using both official and self-report data finds gender to be a strong, consistent correlate of offending patterns (e.g. see, Chesney-Lind, 1997; Puzzanchera, 2009; Zahn, Hawkins, Chicancone \& Whitworth, 2008). For example, Moffitt and colleagues (2001) demonstrated that males engage in significantly more aggressive and violent activities compared to female subjects, a finding echoed in the larger field of research on the gender gap in offending (e.g., Canter, 1982; King \& South, 2011; Mears, Ploeger, \& Warr, 1998; Steffensmeier, 1995; Steffensmeier \& Schwartz, 2004). It is possible that the participation and degree of involvement in serious and violent delinquency may lead potential partners to perceive these males as less respectable and a potential source of domestic violence, therefore, making them less attractive on the marriage market (see Edin et al., 2004).

Although the focus of this work is on the effects of adolescent risk behavior which includes delinquency on partner formation, literature examining the effects of marriage on crime and desistance can further speak to how gender may condition the relationship between risk behavior and partner formation. While some marriage-desistence studies found no significant differences in effects of marriage on desistance from crime when comparing males and females (e.g. see Uggen \& Kruttshnitt, 1998), findings from other, more recent work, suggest otherwise. King, Massoglia, and MacMillan (2007) considered differences in males' and females' likelihood to marry, current marital statuses, and the effects of marriage as a turning point in offenders' lives. Their findings suggested that males, regardless of their marital propensities, are more likely than females to marry partners who have less serious and shorter antisocial histories than themselves or to "marry up" (King et al., 2007:57). These "marrying up" patterns for males 
lent themselves to more successful "knifing off" of past criminal patterns (King et al., 2007; Laub \& Sampson, 2003). On the other hand, females with low-propensities for marriage were more likely than males to become involved with partners who exhibited similar or higher levels of criminal activities (King et al., 2007). King and South (2011) also explored the relationship between criminal behavior and timing of marriage. Importantly, there were no significant gender differences on the timing of first marriage, net of individuals' self-reported criminal histories (King \& South, 2011). However, divergent findings by gender emerged when respondents' desire to marry was removed from statistical models. For females, there was no correlation between criminal histories and marital timing whereas males' criminal offending patterns were significantly associated with delayed marital timing (King \& South, 2011). Taken together, this line of research suggests that the proposed negative effects of adolescent risk behavior and precocious transitions on marriage and even cohabitation may be less for males than females because males tend to "marry up" or partner with more prosocial individuals. However, these unions are not likely to form at an early age. Furthermore, the likelihood of marriage may be decreased further for females due to the characteristics of those individuals with whom they partner (e.g., more antisocial with histories of involvement in risk or problem behavior). Therefore, cohabitation may be the only available option for partner formation for these females.

It may also be that the criteria used to evaluate potential partners as well as the market of potential partners vary across gender leading to differential effects of adolescent risk behavior and precocious transitions on subsequent partner formation. For instance, while both genders evaluate potential mates in terms of the resources they have to offer, historically, males were the breadwinners. As a result, females looking for a partner tend to focus on the socioeconomic resources that a male partner can bring to a relationship whereas males focus on other aspects of 
"attractiveness" in a partner besides socioeconomic resources such as status, trustworthiness, parenting potential, and physical appeal (Kalmijn, 1998). This suggests that males may see the consequences of adolescent risk behavior such as lower educational attainment and financial assistance as less of a detractor among potential partners. However, due to an overall increase in educational attainment and labor market participation among females in the second half of the $20^{\text {th }}$ century, the importance of socioeconomic factors in partner selection are increasingly important among males.

Finally, demographic trends associated with marriage and cohabitation can be used to understand if gender may condition the effects of adolescent risk behavior and precocious transitions on partner formation. About 55\% of individuals ages 25-34 were married in 2000 . Nearly $38 \%$ of females were never married by the age of 30 and $49 \%$ of males had yet to marry by the age of 30 (Jacobsen \& Mather, 2010). This is in line with the finding that the median age of first marriage is higher for males compared to females (i.e., 26.8 versus 25.1 in 2000; Smith, 2006). It is possible that the differential prevalence of marriage in young adulthood across gender may be a function of males needing to be further removed from their involvement in risk or problem behavior in order to be attractive on the marriage market. With respect to cohabitation, national trends reveal that cohabitation increased six-fold since the 1960s, and by 2000 nearly one-half of individuals in their mid-20s to mid-30s lived with a romantic partner at some point in their life (Smith, 2006). Unlike marriage, though, there is a lack of evidence to suggest that trends in cohabitation vary by gender. Therefore, it is likely that cohabitation may be viewed as more appealing to this generation of adults, and it is equally attractive or an acceptable form of partner formation across gender. 
In summary, evidence suggests a "gender gap" in male and female offending rates, the types of offending behavior, the type of partners that antisocial males and females marry, the criteria used to evaluate potential partners, and marriage itself. As a result, the current study conducts all analyses separately for males and females to see if the hypothesized associations vary by gender.

\section{Hypotheses}

Although the research examining the impact of adolescent risk or problem behaviors on partner formation is not extensive, it is supportive of a link between these behaviors and whether people marry or cohabit and the timing of relationship formation. However, most of this research does not look at the possible reasons for this relationship; that is, few studies have incorporated potential mediating variables that might account for why problem behaviors affect marital relations, if they in fact do. Informed by theories of family formation (Becker, 1981; King \& South, 2011; Oppenheimer et al., 1997) and Thornberry and Krohn's (2001) interactional theory, we offer the following hypotheses about the impact of adolescent problem behavior on patterns of partner formation.

1. Adolescent problem behaviors will increase the probability of precocious transitions from adolescence to adulthood including dropping out of high school, becoming a teen parent, and financial stress.

2. Adolescent problem behaviors - including general delinquency, serious delinquency, drug use, and early sexual activity - will reduce the overall likelihood of marriage and early marriage.

3. Adolescent problem behaviors will increase the likelihood of cohabitation and early cohabitation. 
4. The relationships between adolescent problem behaviors and partner relationships will, in part, be mediated by disorderly and precocious transitions (dropping out of high school, becoming a teen parent, and financial stress) from adolescence to adulthood.

5. The life course approach predicts that adolescent problem behaviors will influence patterns of family formation for both males and females, and that precocious transitions will serve as mediators of that relationship, although the specific patterns may differ somewhat by gender.

\section{Methods}

This research utilizes data from the Rochester Youth Development Study (RYDS), a multiwave panel study analyzing the development of delinquency and drug use in an urban sample of adolescents $(n=1,000)$. Data collection began in 1988 when members of the sample were, on average, 14 years of age. A total of 14 waves of data have been gathered during the course of three phases of data collection. The first wave of data collection (Phase 1) covered adolescence, from 14 to 18 years of age. During Phase 1, adolescent respondents were interviewed nine times (waves 1-9) and a parent was interviewed eight times (waves 1-8), at six month intervals. Phase 2 began after a 2.5 year gap in data collection. The respondents and their parents were interviewed at three annual intervals (average age 21-23). Phase 3, waves 13 and 14, consists of respondent interviews at 29 and 31 years of age.

Sample

The RYDS sample was designed to oversample youth who were at high risk for serious delinquency and drug use because the base rates for these behaviors are relatively low (Elliott, Huizinga \& Menard, 1989; Wolfgang, Thornberry \& Figlio, 1987). The target population was 
limited to seventh and eighth-grade students in the public school system of Rochester, NY, a city that has a diverse population and a high crime rate. The sample was then stratified on two dimensions. First, males were oversampled (approximately $75 \%$ versus $25 \%$ ) because they are more likely than females to be chronic offenders and to engage in serious forms of delinquency (Blumstein, Cohen, Roth, \& Visher, 1986). Second, students from areas of the city where larger populations of adult offenders lived were oversampled on the premise that youth residing in these areas are at a greater risk for offending. To identify these areas, each census tract in Rochester was assigned a resident arrest rate reflecting the proportion of the total population living in that tract arrested by the Rochester police in 1986. Subjects were oversampled proportionate to the rate of offenders living in a tract. The arrest rate is included as a control in all estimated equations.

This analysis covers the entire period of data collection (Phases 1-3), from when the adolescents were approximately 14 years old to approximately age 31 . The attrition rate in the RYDS data has been acceptable. By end of Phase 3, 80\% $(n=803)$ of the initial adolescents were retained and interviewed at either Wave 13, Wave 14, or, most likely, both. Comparing the characteristics of respondents who were retained at age 31 to those who left the study on a host of variables demonstrates that attrition did not bias the sample (Bushway, Krohn, Lizotte, Phillips, \& Schmidt, 2013; Thornberry, 2013). For example, there were no significant differences by race/ethnicity or on three major forms of antisocial behavior - self-reported general delinquency, serious delinquency, and drug use.

\section{Measurement}

In order to assess our hypotheses we create measures in four broad clusters: independent variables, mediating variables, outcomes, and control variables. The following is a brief 
description of the measures in each area. Descriptive statistics for all study variables are

presented in Table 1.

Outcomes: Partner Formation

In order to assess the potential effects of adolescent problem behavior on one's marital trajectory, this study considers two different outcomes. The first dependent variable is a binary measure indicating whether or not the respondent was Ever Married. This measure was created using data from waves 6 through $14 .^{1}$ A little over $40 \%$ of the sample indicated that they had been married at some point between wave 6 and wave 14. Our second outcome of interest is a binary measure that indicates whether or not the respondent experienced an Early Marriage (i.e., married prior to the age of 22); around $7 \%$ of the respondents were married prior to the age of 22.

Our first measure of cohabitation is a binary measure indicating whether or not the RYDS respondent Ever Cohabited with a romantic partner without being married, between waves 6 and 14 of data collection. ${ }^{2}$ Just under $74 \%$ of the sample indicated that they had lived with a romantic partner at least once during this time period. Relatedly, we also investigate Early Cohabitation. A binary measure was constructed indicating whether or not each respondent lived with a romantic partner prior to the age of 22 . In our sample, over $32 \%$ of respondents had cohabited prior to their $22^{\text {nd }}$ birthday. Independent Variables: Adolescent Risk Behavior

\footnotetext{
${ }^{1}$ The RYDS survey instrument began asking respondents whether or not they were married beginning in wave 6 . However, none of the RYDS respondents reported being married until wave 8 .

${ }^{2}$ Prior to wave 6, RYDS respondents were asked to name all of the people who lived in one's household, and 3 subjects indicated that a "boyfriend" or "girlfriend" lived in the same household as the respondent in waves 4 and 5. However, these subjects also lived with at least one of their parents. Consequently, it is not possible to determine whether or not the respondent and their partner were actually cohabiting or whether or not the partner was living as a separate individual with the respondent's family.
} 
We use four different measures of adolescent risk behavior collected, on average, at ages 14 and 15 (interview waves 1 through 4). General Delinquency is an incidence measure, which assesses the number of delinquent acts committed across these 4 waves of data collection. This measure includes behaviors ranging from minor acts of delinquency such as shoplifting and petty theft to serious property and violent offenses $(m=39.86$, s. $d .=92.63)$. We also focus more specifically on serious property and violent offenses and use an incidence measure of Serious Delinquency committed across waves 1 through 4 that includes the following behaviors: breaking and entering, theft over $\$ 50$, stealing a car, attacking someone with a weapon, getting into a gang fight, robbery, and rape $(m=3.09$, s. $d .=10.95)$. Similarly, we examine adolescent Drug Use with an incidence measure that indicates the number of times that the respondent used drugs such as marijuana, cocaine, tranquilizers, and so forth between waves 1 and $4(\mathrm{~m}=6.66$, s.d. $=28.42)$. Our final measure of adolescent problem behavior is risky sexual behavior. In this analysis, we focus on a single aspect of sexual risk, early sexual debut (Hofferth \& Hayes, 1987). Our binary measure representing early sexual onset reveals that nearly $35 \%$ of our sample engaged in sexual intercourse prior to the age of 15 .

\section{Mediators: Disorder in the Life Course}

We also examine whether or not the relationship between adolescent risk or problem behavior and subsequent partner formation is mediated by more proximal outcomes associated with early or precocious transitions: failing to graduate from high school, teenage parenthood, and receiving government financial assistance during emerging adulthood. We measure High School Dropout with a binary variable indicating whether or not the adolescent self-reported permanently dropping out of high school before graduation, thus failing to earn his or her high school diploma. If the adolescent subsequently earned a GED they are still counted as a high 
school dropout. Approximately $44 \%$ of this sample dropped out of school. Teenage Parenthood is a binary variable that indicates whether or not the adolescent self-reported giving birth to a child or had a romantic partner give birth to a child at any time before his or her $19^{\text {th }}$ birthday. Nearly $25 \%$ of the respondents indicated that they gave birth or had a partner who gave birth before the age of 19. Finally, we created a measure of financial stress during emerging adulthood reflecting receipt of governmental assistance. Five questions from the wave 10 interview (average age 21) asked respondents if they received any of the following since the last interview (at approximately age 18): food stamps, Aid to Families with Dependent Children (AFDC), welfare/cash assistance/Medicaid, unemployment compensation, or a day care subsidy. These 5 questions were used to create a binary measure where, if the respondent indicated that he or she received at least one of the previously mentioned forms of financial assistance, then he or she was scored as ' 1 ' on Financial Stress. Thirty-three percent of respondents received some type of government financial assistance during emerging adulthood. ${ }^{3}$

\section{Control Variables}

We also include an array of control variables to reduce overestimation of the effects of adolescent risk behavior on subsequent family formation. To account for the socio-economic status of the family of origin, we include two variables: Parent's Education Level refers to the highest grade completed by the principal family wage-earner (range 6 to 13 or more years of

\footnotetext{
${ }^{3}$ Efforts were made to ensure temporal ordering between our independent variables, proposed mediators, and outcomes. There are 5 cases where temporal ordering was an issue between parenthood and cohabitation (cohabitation occurred before teen parenthood), and 4 cases where the subject cohabited prior to dropping out of high school. This results in 8 unique individuals ( 3 females and 5 males). When we remove these cases from the analyses, the results do not change and we report the results for the full sample below. In addition, there are 52 respondents who were either married or cohabiting by the time we asked questions regarding financial assistance. Thus temporal order is difficult to assess. Finally, we acknowledge that it is possible given the time frame of measurement for financial assistance (average age of 18 to the average age of 21) that additional subjects were married or lived with a romantic partner prior to the receipt of financial assistance. However, we were not able to further disentangle the timing of the receipt of financial assistance to further ensure temporal ordering. We return to a discussion of the issue of temporal order concerning financial assistance in the Discussion Section, after the results are presented.
} 
education) and Family Income at Poverty Level is a dichotomous variable indicating whether the family income falls below the federally-defined poverty level for the given family size. We also include a dichotomous variable, Lives with Both Biological Parents, indicating whether the adolescent lives with both biological parents or in some other family constellation during the second wave of data collection (average age 14). We control for Maltreatment Victimization with a binary measure constructed from official substantiated reports of child maltreatment including neglect, physical, and sexual abuse. We account for the Community Arrest Rate using data from the Rochester Police Department. This measure refers to the percentage of the population arrested within the respondent's census tract in 1986. Finally, we control for race/ethnicity (African American, Hispanic and white as the reference category).

Given the numerous variables included in this analysis, we further assessed the impact of attrition (or missing data) from the RYDS sample on our final sample for analysis after listwise deletion $(n=644)$. There were no significant differences in means for any covariate of interest between our final sample and those subjects who had available data on each covariate of interest. Thus, evidence suggests that attrition (or missing data) did not create significant bias in the variables used in this study.

\section{Analytic Plan}

As previously described, we use four different indicators of adolescent risk behavior (i.e. general delinquency, serious delinquency, drug use, and early sexual onset) to ascertain the effects of adolescent problem behaviors on subsequent family formation. First, we look at the direct or main effect of each adolescent problem behavior on the four outcomes of interest (i.e. ever married, early marriage, ever cohabitation, and early cohabitation). Given the binary nature of the outcomes, we use multivariate logistic regression to determine the relationship between 
each individual problem behavior and each respective family outcome controlling for various other factors that may influence family formation. We then examine the relationship between each adolescent problem behavior and the proposed mediators which represent disorder in the life course (i.e., high school drop-out, teenage parenthood, and financial stress during emerging adulthood). Due to the binary nature of each mediator, we use multivariate logistic regression to regress each individual problem behavior on each mediator, while accounting for the control variables. The final step of our analysis involves analyzing the effect of each individual problem behavior during adolescence on subsequent family formation accounting for the potential mediating effects of high school completion, teenage parenthood, and financial stress. To do this, the models include each individual problem behavior and all of the potential mediating variables representing disorder in the life course as well as control variables in order to more adequately describe the relationship between problem behavior in adolescence and subsequent family formation. Recall we estimate all models separately by gender to determine the robustness of our findings across the male and female population.

\section{Results}

We begin by examining the impact of adolescent problem behaviors on patterns of marital formation separately for males and females (Table 2). The odds ratio associated with each independent variable, that is each adolescent risk behavior, comes from a separate equation including the independent variable along with the control variables of race, parent's education level, family poverty level income, family structure, maltreatment victimization, and community arrest rate. Contrary to the first hypothesis, there is no significant impact of any of the problem behaviors on the likelihood or timing of marriage for either the male or female participants (Table 2). 
With respect to patterns of cohabitation (Table 3), the results are gender specific. For the male participants, the likelihood of cohabitation is increased by adolescent involvement in serious delinquency and early sexual onset. Moreover, the likelihood of early cohabitation is increased by adolescent involvement in delinquency, serious delinquency, and drug use. In contrast, for the female participants, none of the adolescent risk behaviors are significantly related to ever cohabiting or early cohabitation at the conventional alpha level of .05. However, the effect of delinquency on cohabitation is marginally significant as is the effect of drug use and early sexual debut on early cohabitation among females.

In general, involvement in adolescent risk behaviors seems to have a greater impact on patterns of cohabitation for males as compared to females. Although there are a smaller number of females available for analysis given the sampling design of the Rochester study, there is still adequate power to detect significant effects for female participants $(n=201)$ given these relatively simple additive models.

The next step in the analysis is to examine the relationship between the adolescent risk behaviors and each of the three proposed mediators: high school drop-out, teenage parenthood, and financial stress. The results are presented in Table 4. As was the case with the earlier analyses, all equations control for race, parent's education level, family poverty level income, family structure, maltreatment victimization, and community arrest rate.

For the male participants, delinquency, serious delinquency, and drug use significantly increase the odds of high school dropout and teenage parenthood, but not financial stress. Early sexual onset is also related to teenage parenthood but not to the other mediators. Given these findings, financial stress cannot serve as a significant mediating pathway for any of the observed 
relationships between adolescent risk behavior and partner formation nor can dropping out of high school mediate the impact of early sexual onset on ever cohabitation.

For the female participants only two of the anticipated relationships are significant. Adolescent drug use and early sexual onset both increase the odds of teenage parenthood. Given these findings and the earlier observation that none of the main effects of adolescent risk behaviors on patterns of partner formation are significant for the females (Tables 2 and 3 ) there is no support for the mediational model among females. Nevertheless, we will examine the full models for the females to see if these precocious transitions are directly related to the outcomes.

The final step in the analysis is to examine the impact of both the adolescent risk behaviors and the precocious transitions on each of the outcomes. Results are presented in Tables 5 through 8. Each block of variables represents a separate equation that includes the specified adolescent risk behavior along with the 3 precocious transitions. It should be noted that the impact of the precocious transition variables is virtually identical across the 4 sets of equations in each table since the only thing that varies across the blocks is the particular risk behavior that is included. As before, the full set of control variables are included in each question. We begin by examining the results for the outcome of ever married (Table 5).

For the male participants teenage parenthood marginally increases the odds of ever marrying. Interestingly, teen parenthood does not increase the odds of marriage for female participants. On the other hand, financial stress appears to decrease the odds of marrying for females. When attention shifts to early marriage, none of the precocious transitions is significantly related to this outcome for either males or females (Table 6).

The final models concern cohabitation (Tables 7 and 8). For the males, teenage parenthood significantly increases the likelihood of ever cohabiting, but it does not appear to 
fully mediate the impact of serious delinquency and early sexual onset on that outcome. For female participants, however, none of the precocious transitions are significantly related to this outcome and involvement in delinquency still marginally increases $(p=.09)$ the likelihood of cohabitation.

The results for early cohabitation are presented in table 8 . For the male participants, high school dropout, teenage parenthood, and financial stress are significantly related to the odds of early cohabitation (although financial stress is only marginally related to early cohabitation when serious delinquency is the adolescent risk behavior included in the model). The odds ratio for teenage parenthood (approximately 4.08) is particularly large. In addition, these variables serve as mediators for the direct effects of delinquency and drug use which no longer have significant effects on the outcome. Although the magnitude of the odds ratio for serious delinquency has diminished, it still remains significant suggesting that dropping out of high school and teenage parenthood only partially mediate the effect of serious delinquency on early cohabitation. For the females, teenage parenthood significantly increases the likelihood of early cohabitation, and dropping out of high school marginally increases the likelihood of living with a romantic partner

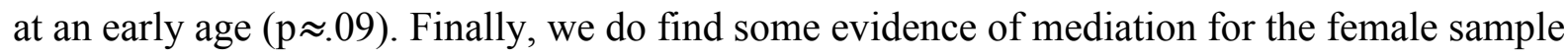
with respect to the outcome of early cohabitation. Results suggest that teenage parenthood mediates the marginally significant relationship between drug use and early cohabitation and the marginally significant relationship between early sexual behavior and early cohabitation.

\section{Summary and Discussion}

Both the life-course framework (Elder, 1994) and interactional theory (Thornberry \& Krohn, 2001) suggest that adolescent risk or problem behaviors will have short- and long-term consequences that disrupt the orderly flow of development. In the short-term, they increase the 
probability of disorderly transitions between adolescence and adulthood and in the long-term, they disrupt successful adjustment to core adult roles. In the present study we were particularly interested in the issue of partner formation and how adolescent risk behaviors influence the processes of partner formation.

Several general conclusions are warranted. First, the likelihood and timing of marriage was not related to adolescent risk behaviors in this sample. Involvement in general delinquency, serious delinquency, drug use, and early sexual debut did not reduce the likelihood of marriage or the likelihood of an early marriage for either the males or females.

Unlike marriage, cohabitation was related to adolescent problem behaviors but only for the male participants. Serious delinquency and early sexual onset increased the likelihood of cohabitation, and general delinquency, serious delinquency, and drug use increased the likelihood of early cohabitation. None of the adolescent risk behaviors were significantly related to either measure of cohabitation at conventional levels, but delinquency was marginally related to ever cohabiting whereas drug use and early sexual onset were marginally related to early cohabitation.

Second, we examined whether life-course theory's hypothesis about precocious transitions helped to mediate or explain relationships between adolescent risk or problem behaviors and patterns of partner formation. In particular, we examined three indicators of disorderly transitions - dropping out of high school, having a child during adolescence, and financial stress as indicated by the receipt of financial assistance. The results vary by gender. For females in the Rochester sample, weak empirical evidence exists in support of the proposed mediation model, but only for early cohabitation. Recall, of all the relationships between the adolescent risk behaviors and partner formation outcomes, only two adolescent risk behaviors, 
drug use and early sexual onset, were marginally related to early cohabitation. In our full models, teenage parenthood appeared to mediate both of these relationships

For male participants, however, there was more consistent support for the proposed mediational model, but only for cohabitation and not marriage. Adolescent risk behaviors were consistently related to two of the proposed mediators: high school dropout and teenage parenthood. Also, those mediators were related to both cohabitation outcomes and appeared to mediate the impact of the earlier adolescent problem behaviors.

Third, although the precocious transitions did not consistently serve as mediating variables as hypothesized, they did have some significant direct effects on the outcomes. For the female participants, financial stress decreased the likelihood of ever marrying. For the males, teenage parenthood increased the likelihood of marriage, ever cohabiting, and early cohabitation. In addition, high school dropout status increased the likelihood early cohabitation.

Overall, there is little evidence in our data that difficulties in adolescence - either involvement in adolescent risk behaviors or experiencing precocious transitions - impact the most normative of partner relationships - marriage. Perhaps the likelihood and timing of marriage is more strongly influenced by more contemporaneous factors. The most consistent impact on marital patterns was observed for the female respondents. Young women who receive governmental assistance payments in emerging adulthood were significantly less likely to marry. However, it is difficult to discern the nature of this relationship from the available data. One possibility is that they were less attractive marriage partners, as suggested by models such as the one proposed by Becker (1981). On the other hand, it is also possible that they refrain from marrying so as not to lose eligibility for welfare payments or they have trouble locating acceptable marriage partners with stable employment given their disadvantaged background and 
social location (Wilson, 1990). This result raises interesting questions that require further investigation.

It is also possible that the failure to find a relationship between adolescent risk behaviors and precocious transitions and marriage reflects the growing opinion in American culture that marriage is becoming obsolete, especially among lower class individuals and minorities (PEW, 2010) as a result of a diminishing number of males who are available to marry and changes in social values (Wilson, 1990) Recall, the sample used in this analysis is predominantly lower class and minority. It is also possible that the increasing age of first marriage for males and females during the time period of investigation affects our analyses given that we only have marriage information on our subjects through age 31 . It would be interesting to follow these subjects for a longer period of time (10 or 20 more years) to see whether the null relationships we found continue to hold. Moreover, the changing norms associated with parenthood and the growing belief that individuals can have families independent of marriage (Rackin \& GibsonDavis, 2012; Reed, 2006; Holland, 2013) may reflect why we did not find a relationship between teenage parenthood and marriage. In fact, national estimates reveal that $41 \%$ of births occur to unmarried mothers, and this number is much higher for African Americans and Hispanics (72\% and 53\%, respectively; PEW, 2010).

In contrast, patterns of cohabitation - the less normative pattern of partner formation - is more common among our sample and more strongly related to earlier adolescent problems. For males in our sample, cohabitation was increased by involvement in adolescent risk behavior and precocious transitions. Perhaps cohabitation represents a continuation of more deviant or problematic patterns of development, especially given the negative relationship between cohabitation and relationship quality and stability (Smock, 2000). On the other hand, it may also 
be that males are using cohabitation as a means to demonstrate their respectability (Edin et al., 2004) and suitability as a partner. Interestingly though the most consistent relationship observed is for teenage parenthood and cohabitation. Adolescent boys who reported having a child during adolescence were themselves more apt to cohabit and do so at an early age, which is in line with recent research suggesting that nonmarital pregnancy is a significant precursor to cohabitation (Lichter, Sassler, \& Turner, 2014). However, we do not know from these data if they were partners with the mother of their child, although that is obviously a possibility and would be in line with the legitimation of cohabitation as a means of shared parenting rather than marriage (Lichter, Sassler, \& Turner, 2014). This finding suggests, therefore, that, at least in the short run, these young males do not shirk their responsibilities as partners and/or fathers, a possibility that requires more detailed investigation. It is also consistent with those of an earlier, more extensive investigation of patterns of father contact and involvement with their children also using the Rochester data (Smith et al., 2005).

The present results raise a number of questions for future research. Two seem most evident. First, there are clear gender differences in the results presented here. The results most consistent with the mediational model derived from life-course theory and interactional theory are observed for male participants. It is not clear why partner formation for the males is more consistently influenced by these earlier adolescent characteristics and behaviors. Perhaps this difference is related to a higher level of male involvement in adolescent risk behavior (see Table 1). We also note that the sample size for males is considerably larger in the Rochester study and we cannot rule out the possibility that the smaller sample of females may have limited our ability to see differences for female participants. As noted earlier though, the female sample $(\mathrm{n}=201)$ should be large enough to detect significant differences in these simple additive models, an 
observation consistent with the fact that several significant relationships were found in our analysis.

These gender differences may also be a result of differences in the availability and desirability of potential partners across gender, especially among lower class individuals. For instance, marriage among lower class black women, who make up a majority of our female sample, is low (Lichter, Sassler, \& Turner, 2014), and this is largely a result of the difficulty that African-American females have in finding an acceptable marriage partner in terms of employment stability and criminal involvement (Wilson, 1990). Similar arguments are made with respect to cohabitation (Wilson, 1990). As a result, the depleted stock of acceptable males combined with the growing acceptance of female-headed households may lead females in our sample to resist forming unions with unacceptable partners whether or not they have a history of adolescent risk behavior or experienced precocious transitions to adulthood. Therefore, it may be that the females, and not potential mates, are driving the partner formation processes and choosing not to cohabit or marry.

In addition, cohabitation itself is a rather heterogeneous status and there are different reasons for cohabiting and different types of cohabiters. For example, Hiekel, Liefbroer, and Poortman (2014) identified 6 types of cohabiters such as those who cohabit as a prelude to marriage and those who cohabit because of potential necessity. Moreover, they demonstrate that there is substantial variability in the proportion of the population that cohabit, and in the type of cohabitation, across 10 European countries. The present study, of course, was conducted in a single American city, Rochester, New York. Whether these findings would apply in other areas of the US or in other countries is unknown. Also, the available data do not allow us to examine sub-types of cohabiters so the relationships reported here should be viewed as an examination of 
cohabitation, in general, that would benefit both from replication in different settings and from more refined measures of cohabitation.

A second area for future research concerns the different pattern of findings for marriage and cohabitation. Given past studies (e.g., King and South, 2011) it is surprising how few characteristics are related to the likelihood and timing of marriage in this study. As stated previously, identifying both the precursors and more contemporaneous influences of marriage is required. Also imperative, future research should unpack the differences between cohabitation and marriage, in terms of precursors, desirability, and consequences, which would further advance life-course study and investigations into partner formation. It would also be advantageous to unpack these differences across class, gender, and racial/ethnic differences in marriage and cohabitation given the varying prevalence of marriage and cohabitation among these social groups.

As is true of all investigations, this one has its limitations. It is based on a sample drawn from a single city, Rochester, New York, at a particular point in time. The sample characteristics may also influence the pattern of findings observed. The sample is overwhelmingly composed of people of color and over represents youth at high risk for serious delinquents. Perhaps a sample with a broader representation, for example, a complete metropolitan area, would yield more variation on the study variables and a different pattern of findings. Replication of this analysis with different samples is certainly needed. Also, as noted above we were not able to completely resolve the issue of temporal order between the independent, mediator, and outcome variables. That was particularly the case for the mediator of financial stress. Even though that is not ideal, it did not alter the substantive conclusions of this analysis. Financial stress was not significantly 
related to the adolescent risk behaviors (where temporal order is correct) and therefore cannot logically serve as a mediator.

Although these and other limitations exist, we believe the current analysis contributes to our understanding of the impact of adolescent problem behaviors on patterns of partner formation. Relying on the longitudinal design of the Rochester Youth Development Study we were able to use prospective data to observe the likelihood and timing of both marriage and cohabitation over an approximately 15 year time span and related that to robust longitudinal measures of several adolescent problem behaviors and several precocious transitions. Doing so suggests that the more normative form of partner relationship - marriage - is not strongly related to earlier problems in life-course development. In contrast, cohabitation is influenced by those earlier characteristics and behaviors, especially for the male members of the Rochester study. 


\section{References}

Armour, S., \& Haynie, D. L. (2007). Adolescent sexual debut and later delinquency. Journal of Youth and Adolescence, 36(2), 141-152.

Arum, R., \& Beattie, I. R. (1999). High school experience and the risk of adult incarceration. Criminology, 37(3), 515-537.

Bachrach, C.A. (1987). Cohabitation and reproductive behavior in the U.S. Demography, 24, 623-637.

Becker, G. (1981). A Treatise on the Family. Cambridge, MA: Harvard University Press.

Bennett, N. G., Bloom, D. E., \& Miller, C. K. (1995). The influence of nonmarital childbearing on the formation of first marriages. Demography, 32(1), 47-62.

Bernburg, J. G., \& Krohn, M. D. (2003). Labeling, life chances, and adult crime: The direct and indirect effects of official intervention in adolescence on crime in early adulthood. Criminology, 41, 1287-1318.

Blomberg, T. G., Bales, W. D., Mann, K., Piquero, A. R., \& Berk, R. A. (2011). Incarceration, education and transition from delinquency. Journal of Criminal Justice, 39(4), 355-365.

Blumstein, A., Cohen, J., Roth, J. A., \& Visher, C. A. (1986). Criminal careers and "career criminals". Panel on Research on Criminal Careers Staff, Committee on Research on Law Enforcement and Criminal Justice. Commission on Behavioral and Social Sciences and Education, National Research Council Staff. Washington, DC: National Academies Press.

Brown, S. L., Sanchez, L. A., Nock, S. L., \& Wright, J. D. (2006). Links between premarital cohabitation and subsequent marital quality, stability, and divorce: A comparison of 
covenant versus standard marriages. Social Science Research, 35, 454-470.

Bushway, S. D., Krohn, M. D., Lizotte, A. J., Phillips, M. D., \& Schmidt, N. M. (2013). Are risky youth less protectable as they age? The dynamics of protection during adolescence and young adulthood. Justice Quarterly, 30(1), 84-116.

Busseri, M. A., Willoughby, T., \& Chalmers, H. (2007). A rationale and method for examining reasons for linkages among adolescent risk behaviors. Journal of Youth and Adolescence, $36(3), 279-289$.

Canter, R. J. (1982). Sex differences in self-report delinquency. Criminology, 20, 373-394.

Centers for Disease Control and Prevention. (2010). Marriage and cohabitation in the United States: A statistical portrait based on Cycle 6 (2002) of the National Survey of Family Growth. Vital and Health Statistics, 23(28). U.S. Department of Health and Human Services. Retrieved from http://www.cdc.gov/nchs/data/series/sr_23/sr23_028.pdf.

Chesney-Lind, M. (1997). The female offender: Girls, women and crime. Thousand Oaks, CA: Sage.

Cherlin, A. J. (2004). The deinstitutionalization of American marriage. Journal of Marriage and Family, 66(4), 848-861.

Cherlin, A.J. (2010). Demographic trends in the United States: A review of research in the 2000s. Journal of Marriage and Family, 72, 403-419.

Clausen, J. A. (1986). Correlates of well-being: Social support and health. Science, 231 (4743), 1315-1316.

Coley, R. L., \& Chase-Lansdale, P. L. (1998). Adolescent pregnancy and parenthood: Recent evidence and future directions. American Psychologist, 53(2), 152-166. 
Collins, R. L., Ellickson, P. L., \& Klein, D. J. (2007). The role of substance use in young adult divorce. Addiction, 102(5), 786-794.

Cunningham, M., \& Thornton, A. (2004, April). The influence of parents' and children's union transitions on attitudes toward cohabitation. Presented at Annual Meeting of the Population Association of America, Boston, MA.

Dannefer, D. (2003). Cumulative advantage/disadvantage and the life course: Cross-fertilizing age and social science theory. Journal of Gerontology, 58B, S327-S337.

DeKlyen, M., Brooks-Gunn, J., McLanahan, S., \& Knab, J. (2006). The mental health of married, cohabiting, and non-coresident parents with infants. American Journal of Public Health, 96(10), 1836-1841.

Doherty, E. E., Green, K. M., \& Ensminger, M. E. (2011). The impact of adolescent deviance on marital trajectories. Deviant Behavior, 33(3), 185-206.

Edin, K. (2000). What do low-income single mothers say about marriage? Social Problems, $47(1), 112-133$.

Edin, K., Kefalas, M. J., \& Reed, J. M. (2004). A peek inside the black box: What marriage means for poor unmarried parents. Journal of Marriage and Family, 66(4), 1007-1014.

Elder, G. H. (1994). Time, human agency, and social change: Perspectives on the life course. Social Psychology Quarterly, 57(1), 4-15.

Elliott, D. S., Huizinga, D., \& Menard S. (1989). Multiple problem youth: Delinquency, substance abuse, and mental health problems. New York: Springer-Verlag.

Elman, C., \& O'Rand, A. M. (2004). The race is to the swift: Socioeconomic origins, adult education, and wage attainment. The American Journal of Sociology, 110(1), 123-160. 
Fagan, J., \& Pabon, E. (1990). Contributions of delinquency and substance use to school dropout among inner-city youths. Youth and Society, 21(3), 306-354.

Farrington, D., \& West, D. (1995). Effects of marriage, separation, and children on offending by adult males. Current Perspectives on Aging and the Life Cycle, 4, 249- 281.

Fu, H., \& Goldman, N. (1996). Incorporating health into models of marriage choice: Demographic and sociological perspectives. Journal of Marriage and Family, 58(3), 740758.

Giddens, A. (1991). Modernity and self-identity. Stanford, CA: Stanford University Press.

Giddens, A. (1992). The transformation of intimacy. Stanford, CA: Stanford University Press.

Giordano, P. C., Cernkovich S. A., \& Rudolph, J. L. (2002). Gender, crime, and desistance: Toward a theory of cognitive transformation. American Journal of Sociology, 107, 9901064.

Hardie, J., \& Lucas, A. (2010). Economic factors and relationship quality among young couples: Comparing cohabitation and marriage. Journal of Marriage and Family, 72(5), 11411154.

Hiekel, N., Liefbroer, A.C., \& Poortman, A.R. (2014). Understanding diversity in the meaning of cohabitation across Europe. European Journal of Population, 30(4), 391-410.

Hofferth, S., \& Hayes, C. (1987). Risking the Future (Vol.2). Washington DC: National Academy Press.

Holland, J. (2013). Love, marriage, and then the baby carriage? Marriage timing and childbearing in Sweden. Demographic Research, 11, 275-306.

Huebner, B. M. (2007). Racial and ethnic differences in the likelihood of marriage: The effect of incarceration. Justice Quarterly, 24(1), 156-183. 
Jacobsen, L. A., \& Mather, M. (2010). U.S. economic and social trends since 2000. Population Bulletin 65(1), Population Reference Bureau. Retrieved from http://www.prb.org/pdf10/65.1unitedstates.pdf

Jessor,R . (1998.) Adolescent risk behavior. NewYork: Cambridge University Press.

Kaestner, R. (1997). The effects of cocaine and marijuana use on marriage and marital status. Journal of Family Issues, 18(2), 145-173.

Kalmijn, M. (1998). Intermarriage and homogamy: Causes, patterns, trends. Annual Review of Sociology, 24, 395-421.

Kennedy, S. \& Bumpass, L. (2008). Cohabitation and children's living arrangements: New estimates from the United States. Demographic Research, 19, 1663-1692.

King, R. D., Massoglia, M., \& MacMillan, R. (2007). The context of marriage and crime: Gender, the propensity to marry, and offending in early adulthood. Criminology, 45, 3365.

King, R. D., \& South, S. J. (2011). Crime, race, and the transition to marriage. Journal of Family Issues, 32(1), 99-126.

Krohn, M. D., Lizotte, A. J., \& Perez, C. M. (1997). The interrelationship between substance use and precocious transitions to adult statuses. Journal of Health and Social Behavior, $38(1), 87-103$.

Krohn, M. D., Thornberry, T. P., Collins-Hall, L., \& Lizotte, A. J., (1995). School dropout, delinquent behavior, and drug use: An examination of the causes and consequences of dropping out of school. In H. B. Kaplan (Ed.) Drugs, Crime, and Other Deviant Adaptations: Longitudinal Studies (pp. 163-183). New York: Plenum Press. 
Lanctot, N., Cernkovich, S. A., \& Giordano, P. C. (2007). Delinquent behavior, official delinquency, and gender: Consequences for adulthood functioning and well-being. Criminology, 45(1), 131-157.

Laub, J. H., Nagin, D. S., \& Sampson, R. J. (1998). Trajectories of change in criminal offending: Good marriages and the desistance process. American Sociological Review, 63(2), 225238.

Laub, J. H., \& Sampson, R. J. (2003). Shared Beginnings, Divergent Lives: Delinquent Boys to Age 70. Cambridge, MA: Harvard University Press

Leverentz, A. M. (2006). The love of a good man? Romantic relationships as a source of support or hindrance for female ex-offenders. Journal of Research in Crime and Delinquency, 43, 459-488.

Lichter, D. T., \& Graefe, D. R. (2001). Finding a mate?: The marital and cohabitation histories of unwed mothers. In L. Wu \& B. Wolfe (Eds.) Out of wedlock: Causes and consequences of nonmarital fertility. New York: Russell Sage Foundation.

Lichter, D.T. (2012). Childbearing among cohabiting women: Race, pregnancy, and union transitions. In Booth, A., Brown, S., Landale, N., Manning, W. \& McHale, S (Eds.), Early adulthood in a family context (pp. 209-219). New York: Springer

Lichter, D.T., Sassler, S., \& Turner, R.N. (2014). Cohabitation, post-conception unions, and the rise in nomarital fertility. Social Science Research, doi: http://dx.doi.org/10.1016/j.ssresearch.2014.04.002.

Lonardo, R. A., Manning, W. D., Giordano, P. C., \& Longmore, M. A. (2010). Offending, substance use, and cohabitation in young adulthood. Sociological Forum, 25(4), 787-803. 
London, A. S., \& Parker, W. M. (2009). Incarceration and living arrangements: Findings from the National Health and Social Life Survey. Journal of Family Issues, 30, 787-812.

Lopoo, L. M., \& Western, B. (2005). Incarceration and the formation and stability of marital unions. Journal of Marriage and Family, 67(3), 721-734.

Manning, W. D., Longmore, M. A., \& Giordano, P. C. (2007). The changing institution of marriage: Adolescents' expectations to cohabit and marry. Journal of Marriage and Family, 69, 559-575.

Mears, D. P., Ploeger, M., \& Warr, M. (1998). Explaining the gender gap in delinquency: Peer influence and moral evaluations of behavior. Journal of Research in Crime and Delinquency, 35, 251-266.

Metzler, C. W., Noell, J., Biglan, A., Ary, D., \& Smolkowski, K. (1994). The social context for risky sexual behavior among adolescents. Journal of Behavioral Medicine, 17(4), 419438.

Moffitt, T. E., Caspi, A., Rutter, M., \& Silva, P. (2001). Sex differences in antisocial behavior: Conduct disorder, delinquency, and violence in the Dunedin longitudinal study. Cambridge, UK: Cambridge University Press.

Moore, K. A., \& Waite, L. J. (1981). Marital dissolution, early motherhood, and early marriage. Social Forces, 60 (1), 20-40.

Newcomb, M. D., \& Bentler, P. M. (1985). The impact of high school substance use on choice of young adult living environment and career direction. Journal of Drug Education, 15(3), 253-261. 
Newcomb, M. D., \& Bentler, P. M. (1988). Impact of adolescent drug use and social support on problems of young adults: A longitudinal study. Journal of Abnormal Psychology, 97(1), 64-75.

Oppenheimer, V. K. (1988). A theory of marriage timing. American Journal of Sociology, 94, 63-91.

Oppenheimer, V. K., Kalmijn, M., \& Lim, N. (1997). Men's career development and marriage timing during a period of rising inequality. Demography, 34(3), 311-330.

PEW Research Center. (2010), The decline of marriage and the rise of new families. Retrieved from http://www.pewsocialtrends.org/2010/11/18/the-decline-of-marriage-and-rise-ofnew-families/.

Puzzanchera, C. (2009). Juvenile arrests 2008. Washington, DC: Office of Juvenile Justice and Delinquency Prevention.

Rackin, H. \& Gibson-Davis, C.M. (2012). The role of pre- and postconception relationships for first time parents. Journal of Marriage and Family, 74, 526-539.

Raley, K., Crissey, S. R., \& Muller, C. (2007). Late adolescent relationships and young adult union formation. Journal of Marriage and Family. 69(5), 1210-1226.

Reed, J.M. (2006). Not crossing the "extra line": How cohabitors with children view their unions. Journal of Marriage and Family, 68, 1117-1131.

Rindfuss, R. R., Swicegood, C. G., \& Rosenfeld, R. (1987). Disorder in the life course: How common and does it matter? American Sociological Review, 52, 785-801.

Sampson, R. J., \& Laub, J. H. (1993). Crime in the making: Pathways and turning points through life. Cambridge, MA: Harvard University Press.

Sassler, S., Miller, A., \& Favinger, S. M. (2009). Planned parenthood? Fertility intentions and 
experiences among cohabiting couples. Journal of Family Issues, 30, 206-232.

Siennick, S. E., \& Osgood, D. W. (2008). A review of research on the impact on crime of transitions to adult roles. In A. M. Liberman (ed.), The long view of crime: A synthesis of longitudinal research (pp. 161-187). New York: Springer.

Smith, T.W. (1998; 2006). American sexual behavior: Trends, socio-demographic differences, and risk behavior. National Opinion Research Center. Retrieved from http://www.norc.org/PDFs/Publications/AmericanSexualBehavior2006.pdf.

Smith, C. A., Krohn, M. D., Chu, R., \& Best, O. (2005). African American fathers: Myths and realities about their involvement with their firstborn children. Journal of Family Issues, 26, $975-1001$.

Smock, P. J. (2000). Cohabitation in the United States: An appraisal of research themes, findings, and implications. Annual Review of Sociology, 26, 1-20.

Smock, P., Manning, W. D., \& Porter, M. (2005). Everything's there except money: How money shapes decisions to marry among cohabitors. Journal of Marriage and Family, 6, 680696.

South S. J. (2001). The variable effects of family background on the timing of first marriage: United States, 1969-1993. Social Science Research, 30(4), 606-626.

Stanley, S. M., Whitton, S. W., \& Markman, H. J. (2004). Maybe I do: Interpersonal commitment and premarital or nonmarital cohabitation. Journal of Family Issues, 25(4), 496-519.

Steffensmeier, D. J. (1995). Trends in female crime: It's still a man's world. In B. R. Price \& N. J. Sokoloff, (Eds), The Criminal Justice System and Women. New York: McGraw- Hill. 
Steffensmeier, D. J., \& Schwartz, J. (2004). Contemporary explanations of women's crime. In B. R. Price \& N. J. Sokoloff, (Eds), The Criminal Justice System and Women. New York: McGraw- Hill.

Tanner, J., Davies, S., \& O'Grady, B. (1999). Whatever happened to yesterday's rebels? Longitudinal effects of youth delinquency on education and employment. Social Problems, 46(2), 250-274.

Thomson, E., \& Colella, U. (1992). Cohabitation and marital stability: Quality or commitment?. Journal of Marriage and the Family, 259-267.

Thornberry, T. P. (1987). Toward an interactional theory of delinquency. Criminology, 25, 863892.

Thornberry, T. P. (2013). Life course continuity and change in antisocial behavior. Final report (5R01MH063386) submitted to the National Institute of Mental Health, U. S. Department of Health and Human Services.

Thornberry, T. P., Smith, C. A., \& Howard, G. J. (1997). Risk factors for teenage fatherhood. Journal of Marriage and Family, 59(3), 505-522.

Thornberry, T. P., \& Krohn, M.D. (2001). The development of delinquency: An interactional perspective. In S. O. White (Ed.), Handbook of Youth and Justice (pp. 289-305). New York: Plenum.

Thornton, A. (1990). The courtship process and adolescent sexuality. Journal of Family Issues, $11(3), 239-273$.

Uggen, C., \& Kruttschnitt, C. (1998). Crime in the breaking: Gender differences in desistence. Law and Society Review, 32, 339-366.

Warr, M. (1998). Life course transitions and desistance from crime. Criminology, 36, 183-216. 
Western, B., Lopoo, L. M., \& McLanahan, S. (2004). Incarceration and the bonds among parents in fragile families. In M. E. Patillo, D. F. Weiman, \& B. Western (Eds.), Imprisoning America: The social effects of mass incarceration (pp. 21-45). New York: Russell Sage.

Wickrama, T., Wickrama, K. A. S., \& Baltimore, D. L. (2010). Adolescent precocious development and young adult health outcomes. Advance in Life Course Research, 15, 121-131.

Willoughby, B., \& Dworkin, J. D. (2009). The relationships between emerging adults' expressed desire to marry and frequency of participation in risk behaviors. Youth \& Society, 40, 426- 450 .

Whyte, M. K. (1990). Dating, Mating, and Marriage. New York: Aldine de Gruyter.

Wilson, W. J. (1990). The truly disadvantaged: The inner city, the underclass, and public policy. Chicago: University of Chicago Press.

Wolfgang, M. E., Thornberry, T. P., \& Figlio, R. M. (1987). From boy to man, from delinquency to crime. Chicago: University of Chicago Press.

Woodward, Fergusson, \& Horwood (2001).

Yamaguchi, K., \& Kandel, D. B. (1985). On the resolution of role incompatibility: A life event history analysis of family roles and marijuana use. American Journal of Sociology, $90(6), 1284-1325$.

Zahn, M. A., Hawkins, S. R., Chiancone, J., \& Whitworth, A. (2008). The Girls Study Group: Charting the way to delinquency prevention for girls. Washington, D.C.: Office of Juvenile Justice and Delinquency Prevention. 
Table 1. Descriptive Statistics, by Gender

\begin{tabular}{|c|c|c|c|c|c|c|c|c|}
\hline & \multicolumn{4}{|c|}{$\begin{array}{c}\text { Males } \\
(\mathrm{N}=443)\end{array}$} & \multicolumn{4}{|c|}{$\begin{array}{l}\text { Females } \\
(\mathrm{N}=201)\end{array}$} \\
\hline & Mean & St. Dev. & Min & Max & Mean & St. Dev. & Min & Max \\
\hline \multicolumn{9}{|l|}{ Outcomes } \\
\hline Ever Married & .44 & - & 0 & 1 & .35 & - & 0 & 1 \\
\hline Early Marriage & .07 & - & 0 & 1 & .07 & - & 0 & 1 \\
\hline Ever Cohabitation & .75 & - & 0 & 1 & .71 & - & 0 & 1 \\
\hline Early Cohabitation & .30 & - & 0 & 1 & .36 & - & 0 & 1 \\
\hline \multicolumn{9}{|l|}{ Adolescent Risk Behaviors } \\
\hline Delinquency & 43.50 & 101.74 & 0 & 870.5 & 32.06 & 67.83 & 0 & 404 \\
\hline Serious Delinquency & 3.53 & 12.18 & 0 & 146.5 & 2.09 & 7.49 & 0 & 69 \\
\hline Drug Use & 7.63 & 31.82 & 0 & 296 & 4.49 & 18.73 & 0 & 165 \\
\hline Early Sexual Onset & .38 & & 0 & 1 & .27 & .44 & 0 & 1 \\
\hline \multicolumn{9}{|l|}{ Mediators } \\
\hline High School Drop-out & .44 & - & 0 & 1 & .42 & - & 0 & 1 \\
\hline Teenage Parenthood & .18 & - & 0 & 1 & .41 & - & 0 & 1 \\
\hline Financial Stress & .19 & - & 0 & 1 & .64 & - & 0 & 1 \\
\hline
\end{tabular}




\begin{tabular}{|lllllllll|} 
Control Variables & & & & & & & & \\
Hispanic & .16 & - & 0 & 1 & .10 & - & 0 & 1 \\
Black & .64 & - & 0 & 1 & .84 & - & 0 & 1 \\
Parent's Education Level & 11.53 & 2.15 & 6 & 18 & 11.23 & 2.08 & 6 & 17 \\
Family Income at Poverty Level & .28 & .45 & 0 & 1 & .38 & .49 & 0 & 1 \\
Lives with Both Biological Parents & .40 & - & 0 & 1 & .27 & - & 0 & 1 \\
Maltreatment Victimization & .15 & - & 0 & 1 & .25 & - & 0 & 1 \\
Community Arrest Rate & 3.92 & 1.98 & .12 & 7.87 & 4.77 & 2.19 & .29 & 7.87 \\
\hline
\end{tabular}


Table 2. The Impact of Adolescent Risk Behaviors on Ever Married, by Gender

\begin{tabular}{|lllll|}
\hline & \multicolumn{2}{c}{ Males $(\mathrm{N}=443)$} & \multicolumn{2}{c|}{ Females $(\mathrm{N}=201)$} \\
\hline & Odds Ratio & P-Value & Odds Ratio & P-Value \\
\hline Ever Married & & & & \\
$\quad$ Delinquency & 1.00 & .76 & 1.00 & .43 \\
Serious Delinquency & 1.01 & .23 & 1.00 & .90 \\
Drug Use & 1.00 & 1.00 & 1.01 & .48 \\
Early Sexual Onset & .94 & .76 & 1.54 & .21 \\
& & & & \\
Early Marriage & & & & .54 \\
Delinquency & 1.00 & .39 & 1.00 & .64 \\
Serious Delinquency & .99 & .62 & .96 & .55 \\
Drug Use & 1.00 & .74 & .96 & .20 \\
Early Sexual Onset & 1.36 & .45 & 2.14 & \\
\hline
\end{tabular}

${ }_{\mathrm{p}}^{\mathrm{p}}<.10 ;{ }^{*} \mathrm{p} \leq .05 ; * * \mathrm{p}<.01 ; * * * \mathrm{p}<.001$ (two-tailed tests)

${ }^{a}$ Each row represents a separate equation including the problem behaviors and the following control variables: race, parent's educational level, family income at poverty level, family structure, maltreatment victimization and community arrest rate.

Table 3. The Impact of Adolescent Risk Behaviors on Ever Cohabitation, by Gender

\begin{tabular}{|c|c|c|c|c|}
\hline & \multicolumn{2}{|c|}{ Males $(\mathrm{N}=443)$} & \multicolumn{2}{|c|}{ Females $(\mathrm{N}=201)$} \\
\hline & Odds Ratio & P-Value & Odds Ratio & P-Value \\
\hline \multicolumn{5}{|l|}{ Ever Cohabitation } \\
\hline Delinquency $^{\mathrm{a}}$ & 1.00 & .13 & $1.01^{\mathrm{f}}$ & .07 \\
\hline Serious Delinquency & $1.08^{*}$ & .03 & 1.04 & .27 \\
\hline Drug Use & 1.01 & .11 & 1.01 & .41 \\
\hline Early Sexual Onset & $1.83 *$ & .02 & 1.70 & .17 \\
\hline \multicolumn{5}{|l|}{ Early Cohabitation } \\
\hline Delinquency & $1.00^{*}$ & .02 & 1.00 & .14 \\
\hline Serious Delinquency & $1.03 * *$ & .01 & 1.01 & .56 \\
\hline Drug Use & $1.01 *$ & .02 & $1.02^{\mathrm{T}}$ & .09 \\
\hline Early Sexual Onset & 1.36 & .17 & $1.79^{\mathrm{T}}$ & .09 \\
\hline
\end{tabular}

${ }^{a}$ Each row represents a separate equation including the problem behaviors and the following control variables: race, parent's educational level, family income at poverty level, family structure, maltreatment victimization and community arrest rate. 
Table 4: The Impact of Adolescent Risk Behaviors on Mediators, by Gender

\begin{tabular}{|c|c|c|c|c|c|c|}
\hline & \multicolumn{6}{|c|}{ Males $(\mathrm{N}=443)$} \\
\hline & \multicolumn{2}{|c|}{$\begin{array}{c}\text { High School } \\
\text { Drop-out }\end{array}$} & \multicolumn{2}{|c|}{ Teenage Parenthood } & \multicolumn{2}{|c|}{ Financial Stress } \\
\hline & Odds Ratio & P-Value & Odds Ratio & P-Value & Odds Ratio & P-Value \\
\hline Delinquency & $1.01 * * *$ & $<.0001$ & $1.00^{* * *}$ & .003 & 1.00 & .22 \\
\hline Serious Delinquency & $1.04 * *$ & .005 & $1.02 *$ & .05 & 1.01 & .50 \\
\hline Drug Use & $1.02 * *$ & .002 & $1.01 * *$ & .005 & 1.00 & .32 \\
\hline \multirow[t]{4}{*}{ Early Sexual Onset } & .89 & .59 & $1.78^{*}$ & .03 & .83 & .46 \\
\hline & \multicolumn{6}{|c|}{ Females $(\mathrm{N}=201)$} \\
\hline & \multicolumn{2}{|c|}{$\begin{array}{c}\text { High School } \\
\text { Drop-out }\end{array}$} & \multicolumn{2}{|c|}{ Teenage Parenthood } & \multicolumn{2}{|c|}{ Financial Stress } \\
\hline & Odds Ratio & P-Value & Odds Ratio & P-Value & Odds Ratio & P-Value \\
\hline Delinquency & 1.00 & .40 & 1.00 & .18 & 1.00 & .41 \\
\hline Serious Delinquency & 1.01 & .76 & 1.00 & .84 & 1.10 & .11 \\
\hline Drug Use & .99 & .33 & $1.04 *$ & .02 & 1.03 & .15 \\
\hline Early Sexual Onset & 1.23 & .54 & $2.89 * *$ & .003 & 1.29 & .50 \\
\hline
\end{tabular}

${ }^{\mathrm{p}} \mathrm{p}<.10 ;{ }^{*} \mathrm{p} \leq .05 ; * * \mathrm{p}<.01 ; * * * \mathrm{p}<.001$ (two-tailed tests)

${ }^{\text {a }}$ Each row represents a separate equation including the problem behaviors and the following control variables: race, parent's educational level, family income at poverty level, family structure, maltreatment victimization and community arrest rate. 
Table 5. The Impact of Adolescent Risk Behaviors and Transition Variables on Marriage, by Gender

\begin{tabular}{|c|c|c|c|c|}
\hline & \multicolumn{2}{|c|}{ Males $(\mathrm{N}=443)$} & \multicolumn{2}{|c|}{ Females $(\mathrm{N}=201)$} \\
\hline & Odds Ratio & P-Value & Odds Ratio & P-Value \\
\hline Delinquency $^{\mathrm{a}}$ & 1.00 & .70 & 1.00 & .37 \\
\hline High School Drop-out & .73 & .14 & .76 & .44 \\
\hline Teenage Parenthood & $1.60^{\mathrm{T}}$ & .08 & .96 & .91 \\
\hline Financial Stress & .79 & .35 & $.49^{\mp}$ & .06 \\
\hline Serious Delinquency & 1.01 & .21 & 1.01 & .68 \\
\hline High School Drop-out & .74 & .12 & .74 & .39 \\
\hline Teenage Parenthood & $1.58^{\mathrm{T}}$ & .09 & 1.00 & .99 \\
\hline Financial Stress & .78 & .33 & $.49^{\mp}$ & .06 \\
\hline Drug Use & 1.00 & .98 & 1.01 & .33 \\
\hline High School Drop-out & .74 & .16 & .77 & .47 \\
\hline Teenage Parenthood & $1.62^{\mathrm{T}}$ & .07 & .94 & .86 \\
\hline Financial Stress & .79 & .36 & $.48^{*}$ & .05 \\
\hline Early Sexual Onset & .88 & .53 & 1.70 & .15 \\
\hline High School Drop-out & .74 & .15 & .72 & .35 \\
\hline Teenage Parenthood & $1.66^{\mathrm{T}}$ & .06 & .88 & .73 \\
\hline Financial Stress & .79 & .35 & $.52^{\mathrm{T}}$ & .08 \\
\hline
\end{tabular}

${ }^{\mathrm{p}} \mathrm{p}<.10 ; * \mathrm{p} \leq .05 ; * * \mathrm{p}<.01 ; * * * \mathrm{p}<.001$ (two-tailed tests)

${ }^{a}$ Each row represents a separate equation including the problem behaviors and the following control variables: race, parent's educational level, family income at poverty level, family structure, maltreatment victimization and community arrest rate. 
Table 6. The Impact of Adolescent Risk Behaviors and Transition Variables on Early Marriage, by Gender

\begin{tabular}{|c|c|c|c|c|}
\hline & \multicolumn{2}{|c|}{ Males $(\mathrm{N}=443)$} & \multicolumn{2}{|c|}{ Females $(\mathrm{N}=201)$} \\
\hline & Odds Ratio & P-Value & Odds Ratio & P-Value \\
\hline Delinquency $^{\mathrm{a}}$ & 1.00 & .32 & 1.00 & .62 \\
\hline High School Drop-out & 1.31 & .52 & .96 & .95 \\
\hline Teenage Parenthood & .75 & .63 & 2.45 & .20 \\
\hline Financial Stress & 1.93 & .15 & .74 & .67 \\
\hline Serious Delinquency & .99 & .58 & .95 & .64 \\
\hline High School Drop-out & 1.20 & .66 & .92 & .89 \\
\hline Teenage Parenthood & .74 & .61 & 2.49 & .19 \\
\hline Financial Stress & 1.89 & .16 & .82 & .77 \\
\hline Drug Use & 1.00 & .79 & .95 & .50 \\
\hline High School Drop-out & 1.14 & .76 & .84 & .80 \\
\hline Teenage Parenthood & .71 & .56 & 2.81 & .13 \\
\hline Financial Stress & 1.85 & .17 & .87 & .84 \\
\hline Early Sexual Onset & 1.47 & .35 & 1.95 & .27 \\
\hline High School Drop-out & 1.18 & .70 & .85 & .80 \\
\hline Teenage Parenthood & .67 & .50 & 2.29 & .24 \\
\hline Financial Stress & 1.90 & .16 & .75 & .68 \\
\hline
\end{tabular}

${ }_{\mathrm{p}}<.10 ; * \mathrm{p} \leq .05 ; * * \mathrm{p}<.01 ; * * * \mathrm{p}<.001$ (two-tailed tests)

${ }^{a}$ Each row represents a separate equation including the problem behaviors and the following control variables: race, parent's educational level, family income at poverty level, family structure, maltreatment victimization and community arrest rate. 
Table 7. The Impact of Adolescent Risk Behaviors and Transition Variables on Cohabitation, by Gender

\begin{tabular}{|c|c|c|c|c|}
\hline & \multicolumn{2}{|c|}{ Males $(\mathrm{N}=443)$} & \multicolumn{2}{|c|}{ Females $(\mathrm{N}=201)$} \\
\hline & Odds Ratio & P-Value & Odds Ratio & P-Value \\
\hline Delinquency $^{\mathrm{a}}$ & 1.01 & .48 & $1.01^{\Phi}$ & .09 \\
\hline High School Drop-out & 1.48 & .12 & .87 & .71 \\
\hline Teenage Parenthood & $3.05 * *$ & .006 & 1.47 & .33 \\
\hline Financial Stress & 1.35 & .35 & 1.76 & .15 \\
\hline Serious Delinquency & $1.06^{\Phi}$ & .07 & 1.04 & .34 \\
\hline Drop-out & 1.40 & .19 & .83 & .60 \\
\hline Teenage Parenthood & $2.97 * *$ & .008 & 1.55 & .26 \\
\hline Financial Stress & 1.31 & .41 & 1.69 & .28 \\
\hline Drug Use & 1.01 & .31 & 1.01 & .62 \\
\hline High School Drop-out & 1.47 & .13 & .85 & .66 \\
\hline Teenage Parenthood & $2.99 * *$ & .01 & 1.48 & .32 \\
\hline Financial Stress & 1.37 & .33 & 1.76 & .15 \\
\hline Early Sexual Onset & $1.81 *$ & .02 & 1.59 & .24 \\
\hline High School Drop-out & $1.60^{\Phi}$ & .06 & .83 & 61 \\
\hline Teenage Parenthood & $2.94 * *$ & .01 & 1.39 & .40 \\
\hline Financial Stress & 1.42 & .27 & 1.86 & .12 \\
\hline
\end{tabular}

${ }_{\mathrm{p}}<.10 ; * \mathrm{p} \leq .05 ; * * \mathrm{p}<.01 ; * * * \mathrm{p}<.001$ (two-tailed tests)

${ }^{a}$ Each row represents a separate equation including the problem behaviors and the following control variables: race, parent's educational level, family income at poverty level, family structure, maltreatment victimization and community arrest rate. 
Table 8. The Impact of Adolescent Risk Behaviors and Transition Variables on Early Cohabitation, by Gender

\begin{tabular}{|c|c|c|c|c|}
\hline & \multicolumn{2}{|c|}{ Males $(\mathrm{N}=443)$} & \multicolumn{2}{|c|}{ Females $(\mathrm{N}=201)$} \\
\hline & Odds Ratio & P-Value & Odds Ratio & P-Value \\
\hline Delinquency $^{\mathrm{a}}$ & 1.00 & .53 & 1.00 & .15 \\
\hline High School Drop-out & $2.51^{* * *}$ & .0002 & $1.86^{\mathrm{F}}$ & .08 \\
\hline Teenage Parenthood & $4.11^{* * *}$ & $<.0001$ & $2.58^{* *}$ & .01 \\
\hline Financial Stress & $1.73 *$ & .05 & .74 & .46 \\
\hline Serious Delinquency & $1.02 *$ & .05 & 1.01 & .52 \\
\hline High School Drop-out & $2.46^{* * *}$ & .002 & $1.77^{\mathrm{T}}$ & .10 \\
\hline Teenage Parenthood & $4.10^{* * *}$ & $<.0001$ & $2.68 * *$ & .008 \\
\hline Financial Stress & $1.71^{\mp}$ & .06 & .74 & .47 \\
\hline Drug Use & 1.00 & .39 & 1.02 & .15 \\
\hline High School Drop-out & $2.51^{* * *}$ & .0001 & $1.85^{\text {f }}$ & .08 \\
\hline Teenage Parenthood & $4.07 * * *$ & $<.0001$ & $2.45^{*}$ & .02 \\
\hline Financial Stress & $1.74 *$ & .05 & .73 & .44 \\
\hline Early Sexual Onset & 1.29 & .30 & 1.48 & .27 \\
\hline High School Drop-out & $2.63 * * *$ & $<.0001$ & $1.77^{\mathrm{T}}$ & .10 \\
\hline Teenage Parenthood & $4.05^{* * *}$ & $<.0001$ & $2.43^{*}$ & .02 \\
\hline Financial Stress & $1.78^{*}$ & .05 & .78 & .54 \\
\hline
\end{tabular}

${ }^{\mathrm{T}} \mathrm{p}<.10 ; * \mathrm{p} \leq .05 ; * * \mathrm{p}<.01 ; * * * \mathrm{p}<.001$ (two-tailed tests)

${ }^{a}$ Each row represents a separate equation including the problem behaviors and the following control variables: race, parent's educational level, family income at poverty level, family structure, maltreatment victimization and community arrest rate. 
Appendix: Correlation Matrix

\begin{tabular}{|c|c|c|c|c|c|c|c|c|c|c|c|c|c|c|c|c|c|c|}
\hline & 1. & 2. & 3. & 4. & 5. & 6. & 7. & 8. & 9. & 10 . & 11. & 12. & 13. & 14. & 15. & 16. & 17. & 18. \\
\hline 1. & 1 & & & & & & & & & & & & & & & & & \\
\hline 2. & .32 & 1 & & & & & & & & & & & & & & & & \\
\hline 3. & .11 & .08 & 1 & & & & & & & & & & & & & & & \\
\hline 4. & .20 & .25 & .41 & 1 & & & & & & & & & & & & & & \\
\hline 5. & .01 & -.03 & .09 & .13 & 1 & & & & & & & & & & & & & \\
\hline 6. & .04 & -.03 & .11 & .13 & .71 & 1 & & & & & & & & & & & & \\
\hline 7. & .01 & -.00 & .08 & .14 & .52 & .30 & 1 & & & & & & & & & & & \\
\hline 8. & -.00 & .04 & .09 & .07 & .07 & .06 & .04 & 1 & & & & & & & & & & \\
\hline 9. & -.07 & .01 & .10 & .26 & .20 & .14 & .16 & -.00 & 1 & & & & & & & & & \\
\hline 10. & -.03 & -.00 & .12 & .27 & .14 & .10 & .16 & .11 & .21 & 1 & & & & & & & & \\
\hline 11. & -.13 & .04 & .06 & .12 & .03 & .03 & .04 & -.04 & .16 & .29 & 1 & & & & & & & \\
\hline 12. & -.15 & -.09 & -.10 & .08 & -.01 & -.01 & -.01 & .16 & -.06 & .12 & .16 & 1 & & & & & & \\
\hline 13. & .08 & .05 & .06 & .11 & .07 & .07 & .07 & -.08 & .10 & .06 & -.09 & -.63 & 1 & & & & & \\
\hline 14. & .00 & .04 & -.05 & -.08 & -.06 & -.06 & -.04 & .01 & -.20 & -.19 & -.11 & .01 & -.23 & 1 & & & & \\
\hline 15. & -.06 & -.05 & .02 & .11 & .08 & .08 & .02 & .02 & .13 & .15 & .11 & .12 & .04 & -.28 & 1 & & & \\
\hline 16. & .04 & -.02 & .05 & -.13 & -.09 & -.09 & -.09 & -.02 & -.09 & -.07 & -.12 & -.18 & .12 & .20 & -.20 & 1 & & \\
\hline 17. & -.04 & -.00 & .09 & .11 & .11 & .11 & .08 & .06 & .13 & .08 & .13 & .03 & -.12 & -.07 & .13 & -.24 & 1 & \\
\hline 18. & -.07 & -.05 & .03 & .05 & .02 & .02 & .01 & -.02 & .07 & .14 & .12 & .25 & .01 & -.27 & .23 & -.08 & -.06 & 1 \\
\hline
\end{tabular}

1. Marriage

2. Early Marriage

3. Cohabitation

4. Early Cohabitation

5. Delinquency

6. Serious Delinquency

7. Drug Use
10. Teenage Parenthood

11. Financial Stress

12. Black

13. Hispanic

14. Parent's Education Level

15. Family Income Below Poverty Line

16. Family Structure 
8. Early Sexual Onset

9. High School Dropout
17. Maltreatment Victimization

18. Community Arrest Rate 